\title{
ICT as a Didactic Tool and Its Use in the Educational Process
}

\author{
Martin Skutil, Martin Maněnová, and Lucie Čermáková
}

\begin{abstract}
The paper is based on the specific research project focused on the possibilities of using modern information and communication technologies in junior primary school. It presents ICT as a didactic tool and outlines the possibilities for its use in educational practice. It also points to teachers' attitudes towards ICT and the reasons why and how they include information and communication technologies into teaching.
\end{abstract}

Index Terms - ICT in education, primary education, ICT as a didactic tool, teachers' attitudes towards ICT.

\section{INTRODUCTION}

New technologies are potential agents for change and innovation. They can motivate students to retreat from passive listening and become more active. They may serve to bring the outside world into the school and in general they induce changes in the way education is provided. The most frequently mentioned in this context is ability to use a foreign language and work with information and communication technologies. An essential presumption for coping with the situation successfully is that the teachers themselves can be well-versed in working with information and communication technologies at the required level [1].

\section{THEORETICAL BACKGROUND}

The Framework Educational Programme for Basic Education [2], a key curriculum document of Czech basic education, presents an educational field of Information and Communication Technology, where it assumes that by the end of the 5th grade of primary school, pupils will be able to use the basic standard functions of a computer, they will be able to work with data, find information on Internet portals, to communicate via the Internet, etc. From this it is clear that we should allow children to meet with new technologies, so they are able to use it effectively, correctly and in accordance with the hygiene and health requirements.

Within the modern teaching facilities, we commonly encounter working with a computer. For primary education we use computers with a variety of educational programs, in some kindergartens we can see the use of KidSmart [3] computed centre. Other representatives of modern information technologies are the Internet and mobile phone [9]. Primary school children commonly use both.

Manuscript received May 9, 2013; revised July 7, 2013.

The authors are with Institute of Primary and preprimary Education, Faculty of Education, University of Hradec Králové, Rokitanského 62, 500 03 Hradec Králové, Czech Republic (tel.: +420 493331 344; e-mail: martin.skutil@uhk.cz).
In the broadest sense, the didactic means are all understood as material resources (such as real objects, phenomena, visual aids, board, etc.) and intangible (e.g. methods, organizational forms of teaching, etc.) natures, which contribute to the overall effectiveness of the teaching process [4]. Duminy, Dreyer, Steven [5] see the educational resources as objects and phenomena to achieve established goals. The means in a broader sense include everything that leads to the fulfilment of educational objectives, compare with [6]. Kalhous and ObstIn Maněnová [7] reported that "the function of didactic material means stems from the fact that a person gains $80 \%$ of the information visually, $12 \%$ of the information audibly, $5 \%$ of the information by touch and $3 \%$ by other senses.

\section{A. ICT Literacy}

Network literacy is most actual in connection with ICT development. It is characterized as ability to identify, use and approach to information in electronic form from information net [8]. At present we understand under the expression net especially internet and its services in this connection. Content of network literacy shifts in direction to work with internet and exploration of its possibilities [9].

In 2002 Bertelsmann Foundation and AOL Time Warner Foundation arranged conference aimed at literacy for $21 \mathrm{st}$ century. Conclusion report from the conference introduces that part of literacy for 21 st century is [10]:

- Technological literacy

- Information literacy

- Medial creativity

- $\quad$ Social skill and responsibility

Technological literacy is described as ability to use media (especially internet) as means for a approach to information. Medial creativity represents ability to understand and take active part in forming content of media. Social skill and responsibility means that man is able to recognize, which social consequences will bring publishing of information and what influence will have these published pieces of information on the youngest generation.

We will meet with the concept of digital competences in professional literature. Digital competences are a set of skills and abilities to solve problems by ICT. It includes even basic knowledge of ICT: use of computers for obtaining, evaluation, storing, forming and exchanging of information and for communication and cooperation in the frame of nets, by means of internet find information and judge their quality [11], [12].

\section{Methodology}

\section{A. Research Method}

The questionnaire ICT in the work of young primary 
school teacher was developed by editing the questionnaire of J. Zounek and K. Šed'ová [13] with the consent of the authors In addition to basic socio-demographic data and information on the frequency of use of different types of information and communication technologies, the questionnaire focused on:

- $\quad$ perception of the situation and teachers' attitudes to ICT,

- $\quad$ perception of barriers and the positive motivational factors,

- the didactic function of technology,

- the power side of work with ICT,

- the role of teacher and group dynamics in a classroom.

The aim of the preliminary research was to verify the research potential of the questionnaire for teachers and gaining initial experience in recording the course of teaching on audio-visual record, and only with a single camera. Subsequently, within the preliminary research, there was integration of evaluation of each activity criteria with the use of the FIAS method. The questionnaire was administered to a group of 18 respondents. The questionnaire as a research tool has undergone statistical testing and we determined its reliability. Expressed by Cronbach's alpha coefficient, the reliability of each questionnaire area was ranging from 0.69 to 0.76 .

The data was processed using the NCSS2007 statistical program.

\section{B. Research Sample}

The questionnaire was distributed to teachers of primary schools in Královehradecký region based on a stratified school selection from the school registry. Administration of the questionnaires took place in person and electronically. Overall, 700 questionnaires was administrated and 263 were returned. The questionnaire return was $37.6 \%$. The research sample in the survey thus consisted of 263 teachers of the first grade of fully organized primary schools, small schools and schools with only the first grade in the Královehradecký region. The respondents' age ranged from 23 years to 65 years, the length of practice was from 0.5 years to 40 years.

\section{RESULTS}

One of the research questions was aimed at ICT didactic functions. Technology influenced the professional competence of teachers, and thus it becomes a part of the professionalism of teachers [13]. So how do teachers use ICT in education in the first grade of primary school? When setting the individual features that ICT can fulfil in teaching, we started from Černochová [14], who defines six types of activities where ICT find their place:

1) Activities focused on the design, planning and preparation of teaching (e.g. searching information for teaching, scheduling, creation of data to work with an interactive whiteboard).

2) Activities aimed at the transfer of knowledge, focused on content of education (e.g. demonstrations, practice and strengthening the curriculum).

3) Activities aimed at teaching management (giving instructions, information focusing on the operation of the school, recording the work of pupils in education).

4) Activities focused on communication and co-operation of students, teachers (recognition of opinions, attitudes, pupils' information about their activities).

5) Activities aimed at further teacher training.

6) Activities aimed at creating a digital portfolio of e-teacher (creating electronic preparation, teaching materials, saving of students' work, other training materials).

Fig. 1 shows that most respondents use technology to extend visual perceptions (48\%), technology plays a fundamental didactic function of material didactic means, i.e. the principle of clarity and multi-channel perception of information, Průcha [15] includes this fact in the intellectual functions of teaching resources, where there is an importance on development of perception, observation, imagination, and also an aesthetic function (development of visual culture and aesthetic sense). ICT is used by $38 \%$ of respondents as a supplement to interpretation as a backdrop. In this case, there is an increasing function of ergonomic (acceleration of perception, to facilitate understanding of the curriculum) and aesthetic. In approximately one third, the technology has become a carrier or source of interpretation and testing tool.

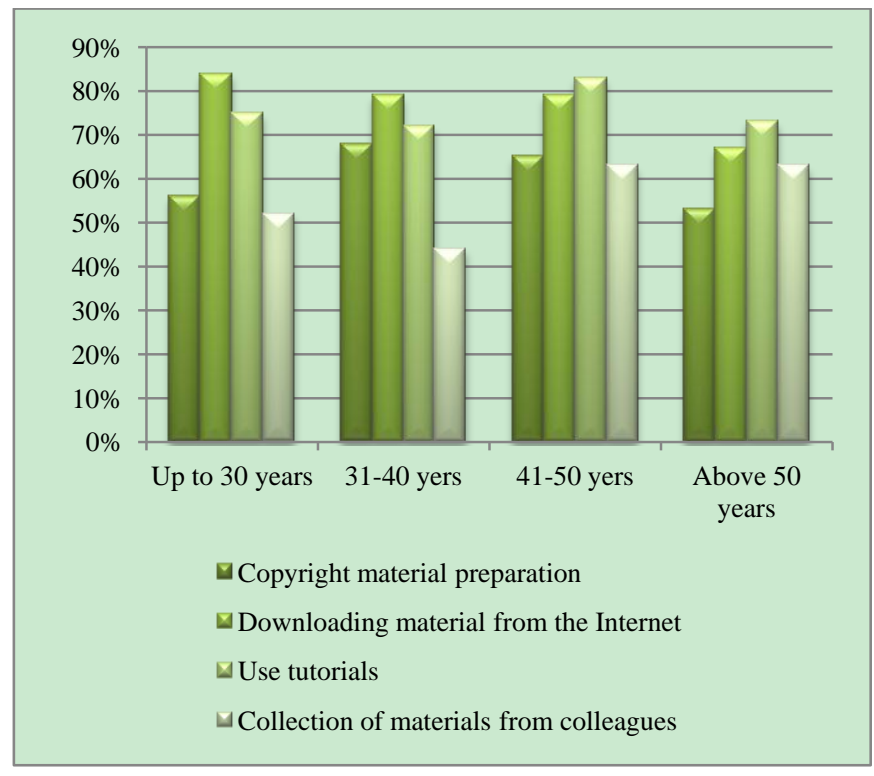

Fig. 1. Ways of ICT use in teaching.

What are the attitudes of teachers towards using ICT, do they feel pleasure when using them or consider their inclusion in education as a necessity? We put the question of whether teachers consider the use of ICT as a pleasure or necessity in relation with the ways of ICT use. The results of our survey are shown in Fig. 2 (none of the respondents chose the answer - futility in the questionnaire). The respondents could choose more options of ICT use and didn't have to comment on each of the options, so the totals in the rows do not amount to a total of $100 \%$.

It can be seen that the teachers who work with ICT which brings "pleasure" use them mostly as a source of interpretation (54\%) and for the expansion of visual perception and the abilities of students integrate technologies twice more than those who consider ICT as necessity. Other items are comparable, there is no significant different in use 
of ICT in teaching according to attitudes of the respondents. In our opinion, we can observe with concern the statement of enthusiastic respondents (they consider ICT as a pleasure) in the last item, when they use ICT as a complement in their interpretation, as a backdrop. The value of $43 \%$ is relatively high and may lead to the conclusion that these teachers fill their lessons with technologies, and this may have a negative rather than a positive impact on pupils learning.

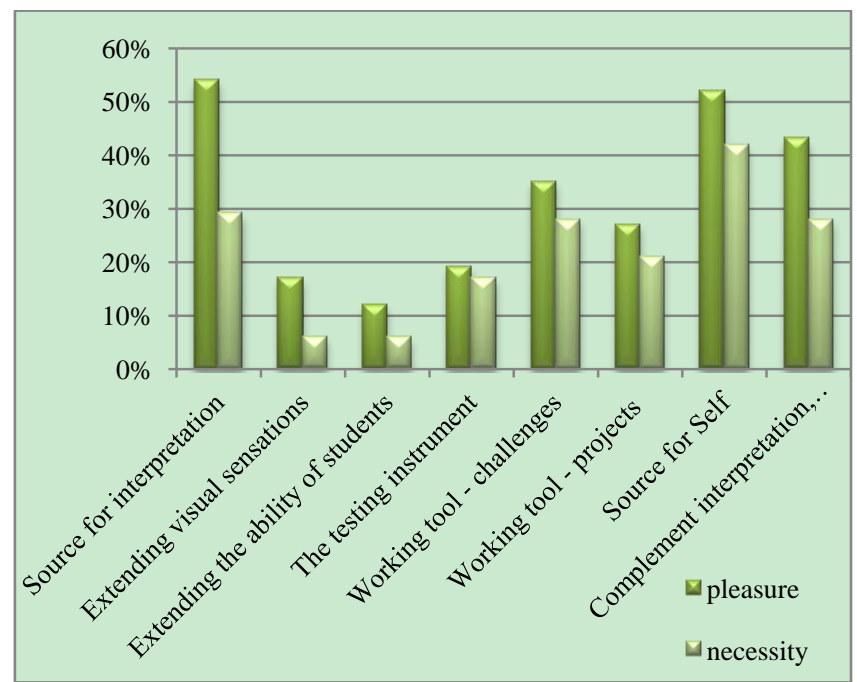

Fig. 2. The way of ICT use in teaching according to their attitudes towards ICT.

A further aim in the research was to describe the effort going, processes, relationships, and changes taking place in a classroom and to describe the social dynamics in a classroom. The data show (Fig. 3) that students work independently (74\% of respondents expressed this fact), but group work is also very strongly represented (58\%). It turns out that in teaching there are traditional organizational forms of teaching (individual work) as well as forms (group work) that fall into non-traditional forms of teaching [15]. It is interesting to note that more respondents $(77 \%)$ reported that students work together, in other words it is a co-operative learning. The highest percentage in terms of social dynamics in a classroom is given to individualization of pupils' work $(89 \%)$. It means that students often work individually, the teacher must allow for different levels of student performances, must be prepared for this reality and ensure more activities for "faster" pupils. Age of the respondents did not affect the answers $(p=0,65)$.

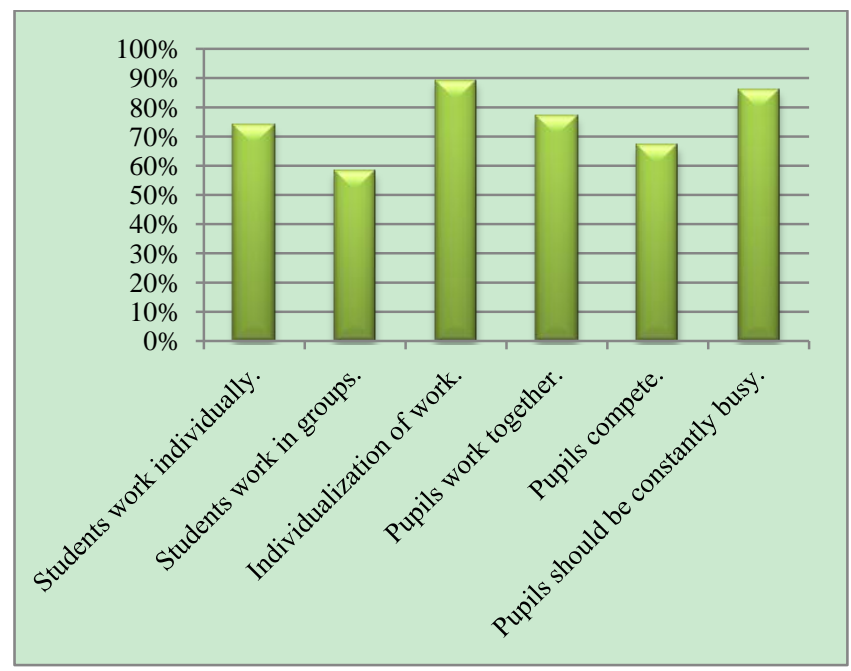

Fig. 3. Social dynamics in a classroom when using ICT.

Elsewhere, we have already analysed the motives that lead teachers to use ICT. We focused on the "tension" and "pressure" sides. We encountered opinions of teachers that children like work with ICT, it is interesting for them and it becomes a matter of course (see below the focus groups). Is there any other reason why teachers use ICT? To answer the question, we used a factor analysis with an attempt to identify the types of teachers according to the selected strategies (Table I).

\begin{tabular}{|c|c|c|c|c|}
\hline Questionnaire item & $\begin{array}{l}\text { Factor1 } \\
\text { expert }\end{array}$ & $\begin{array}{l}\text { Factor 2 } \\
\text { controlling }\end{array}$ & $\begin{array}{l}\text { Factor } 3 \\
\text { externalization }\end{array}$ & $\begin{array}{l}\text { Factor } 4 \\
\text { regulative }\end{array}$ \\
\hline I use ICT primarily because children like working with it. & 0.160382 & 0.191152 & 0.029468 & 0.381985 \\
\hline $\begin{array}{l}\text { If I don't know anything in the lesson, I show to students how to } \\
\text { search the required information by using ICT. }\end{array}$ & 0.192282 & 0.232186 & 0,699557 & 0.407090 \\
\hline $\begin{array}{l}\text { I use ICT to recur or strengthen knowledge of the topic, which I } \\
\text { interpret to students (I search information on the Internet, I watch } \\
\text { television documentaries). }\end{array}$ & 0.179206 & 0.224860 & 0.256526 & 0.059496 \\
\hline $\begin{array}{l}\text { If the class doesn't behave, I restrict work with ICT (we don't use } \\
\text { computers, I don't play a film to them, etc). }\end{array}$ & 0.061233 & 0.487401 & 0.006382 & 0.128366 \\
\hline $\begin{array}{l}\text { I use tutorials that show whether students succeed in the assigned tasks } \\
\text { (percent, marks, revealing of images, etc.). For good performance I } \\
\text { give them marks. }\end{array}$ & 0.335723 & 0.224900 & 0.110891 & 0.054339 \\
\hline I use ICT in lessons as relaxation activity. & 0.381433 & 0.193902 & 0.143745 & 0.689147 \\
\hline $\begin{array}{l}\text { If in a lesson we work with ICT, I give them tasks that can be solved in } \\
\text { different ways and about which results I don't know in advance. }\end{array}$ & 0.322526 & 0.214309 & 0.093827 & 0.153589 \\
\hline $\begin{array}{l}\text { When working with ICT I watch children and in the case of } \\
\text { problematic behaviour I act (I disconnect the Internet, I put them back } \\
\text { to the correct location in the tutorial, I limit unwanted communication } \\
\text { between students, etc.). }\end{array}$ & 0.186596 & 0.551763 & 0.047534 & 0.053904 \\
\hline $\begin{array}{l}\text { When students work with educational programs that mark their } \\
\text { performance, I try to help them so they can achieve a better result }\end{array}$ & 0.411904 & 0.242475 & 0.416928 & 0.515922 \\
\hline $\begin{array}{l}\text { When a pupil meets all the tasks in a lesson on the PC, they can freely } \\
\text { use the computer (internet, games, etc.) }\end{array}$ & 0.384815 & 0.428522 & 0.48627 & 0.084696 \\
\hline
\end{tabular}

The obtained data were subjected to a factor analysis, we considered 3 to 6 factors. Based on the results, we opted to four factors. Next to each factor there are indicated items of the questionnaire that the most relevant factor full. The first 
factor corresponds to the type of teacher who can work with technologies and is an expert in the field. The second factor describes a teacher who uses technologies to control and organize teaching. The third factor corresponds to a teacher, who partially transmits their activities on technologies, and the fourth factor represents a teacher who uses technologies primarily to motivate pupils.

\section{CONCLUSIONS}

The aim of our research survey was to determine in what way teachers mostly use ICT in educational practice. It turns out that ICT is mostly used as a supplement to interpretation and as a visual communication support for teachers. It is also an interesting and innovative way of testing and for the independent work of pupils. We perceive as positive the fact that teachers use ICT in the teaching of different didactic categories, not only as a motivational tool, as is the case in recent times, but also as a new way of passing information and also the support of information of students, which is nowadays shown as a necessary part of preparing students for lifelong learning.

\section{ACKNOWLEDGEMENTS}

This paper was written as part of a specific research project of the Faculty of Education, University of Hradec Králové No. 2103/2012Analysis of elementary lessons using the interactive whiteboard with a focus on teaching interaction and communication.

\section{REFERENCES}

[1] M. Maněnová, M. Skutil, and P. Zikl, "Takingadvantageof ITC by teachersattheprimaryschool," Educationaltechnologies (EDUTE'10), Athens: WSEAS Press, 2010.

[2] Framework Education Programmefor Basic Education. (2007) [Online]. $\quad$ pp. $126 . \quad$ Available: http://www.vuppraha.cz/wp-content/uploads/2009/12/RVPZV_200707.pdf.

[3] M. Maněnová and M. Skutil, "ICT and audiovisualtechnic in nurseries in the Czech Republic," presented at International Conference on AppliedComputer Science (ACS'10), Athens: WSEAS Press, 2010.

[4] K. Götz and P. Häfner, Didactic Organization of Teaching and Learning process, Frankfurt amMain: Peter Lang, 2004.

[5] P. A. Duminy, H. J. Dreyer, and P. D. G. Stevn, Education for the student teacher, Pearson South Africa, 1990.

[6] C. Goldin and L. F. Katz, Theracebetween education and technology, Harvard University Press, 2008.

[7] M. Maněnová et al., ICT and a Teacheratan Elementary School, Brno: ComputerPress, a. s., 2009.

[8] Ch. R. McClure, "Network literacy: A Role forLibraries?" Information Technology and Libraries, Chicago, Illinois: American Library Association, pp. 115-125, 1994.

[9] P. Woessner. (2008). $21^{\text {st }}$ Century Literacy: Network Literacy. [Online]. Available:

http://pwoessner.com/2008/12/15/21st-century-literacy-network-litera cy/.

[10] Bertelsmannfoundation. (2002). Whitepaper: 21st Century Literacy Summit. [Online]. Available: http://web.archive.org/web/20040210141444/www.21stcenturyliterac y.org/white/index.htm.
[11] S. Bunt-Kokhuis and M. Bolger. Talent competences in thene we Learning generation. [Online]. (15). Available: http://www.elearningeuropa.info/files/media/media19740.pdf.

[12] Recommendation of the European Parlament and of the Council. (2005) [Online]. http://ec.europa.eu/education/policies/2010/doc/keyrec_en.pdf.

[13] J. Zounek and K. Šed'ová, Učitelé a technologie: Mezi tradičním a modernim pojetím (Teachers and Technologies: BetweenTraditional and ModernConcept), Brno: Paido, 2009.

[14] M. Černochová, Príprava budoucích e-učitelů na e-instruction (Trainingof e-Teachersforan e-Instruction), Praha: ASIS, 2003.

[15] J. Průcha, Pedagogická encyklopedie (PedagogicalEncyclopedy), Praha: Portál, 2009.

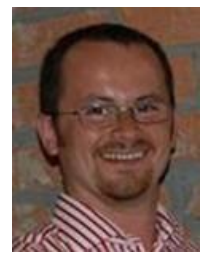

Martin Skutil was born in Hradec Králové, Czech Republic in 1978. He earned Master degree in a field of Education at the Faculty of Education, University of Hradec Králové in 2002. After that he moved to the Faculty of Arts, Masaryk University n Brno, where he earned Doctoral degree (Ph.D.) in a field of Education in 2009.

He works at the Institute of Primary and Preprimary Education, Faculty of Education, University of Hradec Králové in the Czech Republic since 2005. At the present time (since 2009), he is a secretary of the Institute. He cooperates with different foreign institutions. He is also solver and co-solver of many research and development projects. He wrote a book focused on methodology of education research and published many articles, e.g. SKUTIL, Martin a MANĚNOVÁ, Martina. Interactive white board in the primary school environment. International Journal of Education and Information Technologies, 2012, Issue 1, Volume 6, pp. 123-130. ISSN 2074-1316; SKUTIL, Martin.Cognitive maps - activating method in primary education. In ICEEM 2012 - 2nd International Conference on Economic, Education and Management. Vol. 1. Hong Kong: Hong Kong Education Society, 2012. s. 63-67. ISBN 978-988-19750-3-4. and many others. His field of interest is General didactics with a view on teaching methods and ICT, Methodology of educational research and Comparative education.

Dr. Skutil is member of Czech Education research association (belongs to European Education Research Association) and also member of Czech Education Society. He presented articles at many conferences around the world and published other articles in European journals. He has been lecturing in different European countries.

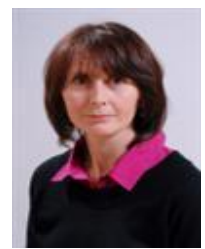

Martina Maněnová was vorn in Jaroměr̆, Czech Republic, 1964.She earned Master degree in Teacher Study Programme Faculty of Education HradecKrálové (physics - basic techniques) in 1987, 2003 - Doctoral Study Programme in Faculty of Science of MatejBel University of Banska Bystrica, Slovakia (Ph.D.). In 2012 she was named Associate professor in Primary Education.

Now she is anAssociate professor at Faculty of Education of University Hradec Králové (ICT, Technical Education, and Didactics of science) and Vice-dean for lifelong education and practice. She participated in projekts "Evaluation of the modern technologies contributing towards forming and development university students' competences," "Comparative analysis of e-learning system Moodle and WebCT, with a focus on technical and humanities", " Research skills of teachers and students in the use of ICT to primary school“. Selected publications: ICT in teacher training of Primary School (Brno, Czech Republic, Computer Press, 2009), SKUTIL, Martin a MANĚNOVÁ, Martina. Interactive white board in the primary school environment. International Journal of Education and Information Technologies, 2012, Issue 1, Volume 6, pp. 123-130. ISSN 2074-1316.Teacher of Primary Education in relation to ICT (Hradec Králové, Czech republic, Gaudeamus, 2009) and many others.

Dr. Maněnová is a member of professional bodies: Czech Statistical Society, Czech Association of Educational Research. She presented articles at manyconference around the world and published other articles in European journals.

Lucie Čermáková is a teacher trainee at the Institute of Primary and Preprimary Education, Faculty of Education, University Hradec Kralove in the Czech Republic. Her field of interest is ICT in education. 